\title{
TBX3 Gene
}

National Cancer Institute

\section{Source}

National Cancer Institute. TBX3 Gene. NCI Thesaurus. Code C101638.

This gene is involved in both transcriptional repression and limb development. 